\title{
PERLINDUNGAN HUKUM BAGI ANAK SEBAGAI KORBAN KEKERASAN FISIK YANG BERDAMPAK PSIKIS TERHADAP KEBERLANGSUNGAN PENDIDIKAN FORMAL ANAK
}

\author{
-Wardatul Muchlisoh-
}

\begin{abstract}
ABSTRAK
Kekerasan yang berdampak psikis terhadap pendidikan anak saat ini belum diatur secara jelas dalam undang-undang Indonesia. Undang-undang hanya menjelaskan mengenai macam-macam bentuk dan aturan mengenai kekerasan secara umum. Permasalahan akan terjadi ketika seorang anak (pelajar) mengalami kekerasan baik itu kekerasan fisik, psikis, ataupun seksual yang berdampak pada psikis korban tidak dapat menuntut pertanggungjawaban pelaku, karena kasus kekerasan tersebut jika dibawa ke ranah hukum, maka pelaku hanya dikenai pasal terkait kekerasan yang nampak atau luka yang terlihat. Sedangkan untuk dampak psikis yang dirasakan korban tidak ada aturan untuk memberikan sanksi bagi pelaku kekerasan untuk bertanggung jawab terhadap keadaan psikis korbannya. Tujuan dalam penulisan hukum ini adalah untuk mengetahui dan menganalisis pengaturan jaminan perlindungan hukum bagi anak korban kekerasan fisik yang berdampak psikis terhadap keberlangsungan pendidikan formal anak dan juga untuk mengetahui bentuk pengaturan perlindungan hukum yang tepat bagi anak korban kekerasan fisik yang berdampak psikis terhadap keberlangsungan pendidikan formal anak. Penulisan hukum ini menggunakan jenis penelitian yuridis normatif dan Penelitian ini juga menggunakan metode analisis deskriptif kualitatif.
\end{abstract}

Kata Kunci :Perlindungan Hukum, Kekerasan, Psikis, Pendidikan Anak

\begin{abstract}
Violence that has a psychological impact on children's education is currently not clearly regulated in Indonesian law. The law only explains the various forms and rules regarding violence in general. Problems will occur when a child (student) experiences violence, be it physical, psychological, or sexual violence that has an impact on the victim's psychological can not hold the perpetrator accountable, because if the case of violence is brought to the law, the perpetrator will only be subject to the article related to violence or visible wounds. As for the psychological impact felt by the victims there are no rules to sanction perpetrators of violence to be responsible for the psychological state of their victims. The purpose of writing this law is to know and analyze legal protection guarantees for children victims of physical violence that have psychological impact on the continuity of formal education of children and also to determine the appropriate form of legal protection for children victims of physical violence that have psychological impact on the sustainability of children's formal education. This legal writing uses a type of normative juridical and this study also uses a qualitative descriptive analysis method.
\end{abstract}

Keywords: Legal Protection, Violence, Psychic, Children's Education

\section{PENDAHULUAN}

Komisi Perlindungan Anak Indonesia mencatat pengaduan terkait dengan persoalan anak sebanyak 3.849 kasus pada tahun 2017 ini lebih banyak jika dibandingkan dengan tahun sebelumnya. ${ }^{1}$ Tahun 2018 banyak diketahui oleh masyarakat bahwa di sekolah tempat yang seharusnya digunakan anak-anak untuk

\footnotetext{
1 Dedi Hendriani, "Catatan Akhir Tahun KPAI meneropong Persoalan Anak" dalam http://www.kpai.go.id/berita/catatan-akhir-tahun-kpaimeneropong-persoalan-anak, diakses tgl. 31 Desember 2017
}

menimba ilmu malah menjadi salah satu tempat berbahaya bagi anak-anak. Hal ini karena banyaknya kasus kekerasan yang dialami oleh anak di lingkungan belajar mereka yakni di sekolah.

Menurut KPAI, kekerasan di sekolah paling banyak terjadi, Kekerasan disatuan pendidikan cukup tinggi, baik yang dilakukan guru pada siswa, siswa terhadap guru, maupun siswa terhadap siswa lainnya. Data pengaduan di KPAI didominasi oleh kekerasan fisik (72\%). Yang kemudian diikuti dengan kekerasan psikis (9\%), kekerasan finansial atau 
pemalakan/pemerasan (4\%) dan kekerasan seksual (2\%). ${ }^{2}$ Selain itu kasus bullying menjadi kasus tertinggi. Paparan kasus-kasus tersebut yaitu kekerasan seksual guru yang tidak dilaporkan ke KPAI sekitar 13\%, kekerasan psikis sekitar 9\%, kekerasan seksual sekitar $2 \%$ sedangkan kekerasan fisik dan anak korban kebijakan mencapai $26 \%{ }^{3}$

Menurut kamus besar bahasa Indonesia (KBBI), istilah kekerasan adalah perihal (yang bersifat, berciri) keras; perbuatan seseorang atau kelompok orang yang menyebabkan cedera atau matinya orang lain atau menyebabkan kerusakan fisik atau barang orang lain; paksaan dan suatu perbuatan yang menimbulkan kerusakan fisik atau non fisik (psikis). Dalam hukum publik dan privat, kekerasan merupakan sebuah ekspresi baik yang diakukan secara fisik ataupun secara verbal yang mencerminkan pada tindakan agresi dan penyerangan pada kebebasan atau martabat seseorang yang dapat dilakukan oleh perorangan atau sekelompok orang umumnya berkaitan dengan kewenangannya yakni bila diterjemahkan secara bebas dapat diartikan bahwa semua kewenangan tanpa mengindahkan keabsahan penggunaan atau tindakan kesewenang-wenangan. ${ }^{4}$

Kekerasan menurut bentuknya dapat digolongkan menjadi beberapa macam yaitu kekerasan fisik, kekerasan psikologis atau mental, dan kekerasan struktural. ${ }^{5}$ Indonesia adalah negara hukum, maka perlindungan hukum yang tepat bagi anak yang mengalami

${ }^{2}$ Vicentius Jyestha, "KPAI Soroti Kasus Kekerasan Pendidikan yang Masih Tinggi" dalam http://www.tribunnews.com/nasional/2018/05/02/kpaisoroti-kasus-kekerasan-pendidikan-yang-masih-tinggi, diakses tgl. 2 Mei 2018

3 Lihat Anonim, "KPAI: Terjadi 33 Kasus Kekerasan Pada Anak Selama April-Juli 2018” dalam https://www.idntimes.com/news/indonesia/indianamalia/ kpai-terjadi-33-kasus-kekerasan-pada-anak-selama-apriljuli/full, diakses tgl. 13 Agustus 2018

4 Lihat Anonim, "Kekerasan" dalam https://id.wikipedia.org/wiki/kekerasan, diakses tgl. 23 Januari 2018

5 Lihat Anonim, "Macam-macam Kekerasan" dalam http://ssyarof.blogspot.co.id/2013/06/macammacam-kekerasan.html, diakses tgl. 10 Juni 2013 kekerasan diperlukan untuk melindungi hakhak anak. Hak-hak anak itu seperti salah satunya mendapatkan pendidikan yang baik.

Dalam Pasal 5 Undang-undang RI Nomor 20 Tahun 2003 Tentang Sistem Pendidikan Nasional selanjutnya disebut undang-undang pendidikan Ayat (1) mengatur bahwa Setiap warga negara mempunyai hak yang sama untuk memperoleh pendidikan yang bermutu; sedangkan dalam Ayat (5) Setiap warga negara berhak mendapat kesempatan meningkatkan pendidikan sepanjang hayat. Maka hak bagi anak untuk memperoleh pendidikan sangatlah penting dan dijamin oleh peraturan perundangundangan.

Salah satu kasus kekerasan yang terjadi pada anak yaitu kasus kekerasan yang dialami oleh seorang siswi Sekolah Dasar yang sering diejek oleh siswi SMP di Thamrin City. Peristiwa terjadi pada Jumat, 14 Juli 2017 sekitar pukul 13.30 WIB. Berawal dari saling menghina antara korban dan pelaku, karena merasa dendam si pelaku merasa tidak puas. Keesokan harinya pelaku mencegat dan meminta korban untuk bertemu di Thamrin City sepulang sekolah, disanalah pelaku dengan temannya melakukan penganiayaan pada korban. Penganiayaan itu direkam dan disebarkan ke media sosial oleh temannya yang lain. ${ }^{6}$

Berdasarkan kasus di atas, yang paling terlihat adalah kekerasan fisik yang dialami oleh korban. Terlihat pula bahwa kekerasan fisik yang terjadi tersebut selalu diawali oleh kekerasan psikis, entah dimulai dari saling ejek mengejek, rasa tidak suka berlebihan hingga mengeluarkan kata-kata makian dan lain-lain sehingga akhirnya terjadilah kekerasan fisik. Jika melihat secara kasat mata maka akan terlihat bahwa korban hanya mengalami dampak fisik seperti lebam-lebam, dan luka lainnya. Namun jika diteliti lebih dalam maka

${ }^{6}$ Cici Marlina Rahayu, "Begini Urutan Kejadian Siswi SMP Bully Siswi SD di Thamrin City" dalam http://news.detik.com/berita/d-3562776/begini-urutankejadian-siswi-smp-bully-siswi-sd-di-thamrin-city, diakses tgl. 17 Juli 2018 
korban tidak hanya memiliki dampak fisik saja, tetapi juga dampak psikis yang memang secara kasat mata tidak terlihat hanya saja akan dirasakan oleh korban tersebut ketika korban mengingat peristiwa yang telah dialaminya.

Melihat banyaknya kasus kekerasan di lingkungan sekolah kerap kali kekerasan yang terjadi yaitu kekerasan fisik, seksual dan psikis. Dari berbagai kekerasan tersebut dampak yang pasti akan dialami oleh korban kekerasan yaitu dampak psikis terhadp korban. Jika dampak dari kekerasan fisik yang dialami oleh anak dapat sembuh dengan mudah lain halnya dengan berdampak psikis yang dialami oleh anak korban kekerasan. Anak yang telah terganggu psikologinya secara tidak langsung memiliki dampak seperti rasa takut yang berlebihan, lebih menutup diri, tidak memiliki semangat untuk bersekolah akibat trauma yang pernah dirasakannya, pendidikan yang mulai terabaikan begitu saja, hingga memliki pemikiran negatif untuk mengakhiri hidup.

Kekerasan fisik yang berdampak psikis pada anak berarti bahwa anak tersebut telah merasakan kekerasan psikis. Namun tidak ada cara yang menentukan seberapa parah kekerasan psikis yang telah dialami sehingga hukum di Indonesia tidak dapat memproses lebih lanjut. Bahkan dalam suatu kasus ketika dipersidangkan di pengadilan, korban (anak) hanya diberi keadilan akan kekerasan fisik yang dialaminya saja sedangkan kekerasan psikis yang terjadi dan/atau dampak psikis yang dialaminya tidak dapat dimintai keadilan. Hal ini karena aturan terkait hukuman kekerasan psikis dan/atau dampak psikis masih belum diatur secara jelas dalam undangundang.

Aturan yang terdapat di dalam undangundang perlindungan anak masih dianggap kurang memberikan perlindungan bagi anak korban kekerasan dan masih belum dijelaskan lebih detail berkaitan mengenai dampak psikis yang dapat terjadi pada anak. Sehingga penegak hukum akan kesulitan untuk memproses kasus yang berkaitan dengan dampak psikis pada anak.
Dalam penelitian ini, penulis menggunakan metode pendekatan yuridisnormatif yaitu suatu metode pendekatan ilmiah untuk menemukan kebenaran berdasarkan logika keilmuan hukum dari sisi normatifnya. Adapun jenis data yang digunakan terdiri dari tiga bahan hukum yaitu bahan hukum primer sebagai bahan hukum yang mengikat, bahan hukum sekunder sebagai hasil olahan pendapat atau pikiran pakar-pakar ahli di bidangnya yang memberi petunjuk dan bahan hukum tersier yang memberikan pemahaman dan pengertian untuk mendukung bahan hukum primer dan sekunder. Metode pengumpulan data dalam penelitian ini dilakukan melalui dengan melakukan studi kepustakaan. Analisis data yang digunakan dalam penulisan ini adalah dengan metode analisis deskriptif kualitatif yaitu menyajikan kajian pada datadata yang diperoleh dari objek penelitian.

\section{HASIL PENELITIAN}

A. Pengaturan Jaminan Perlindungan Hukum bagi Anak Korban Kekerasan Fisik yang Berdampak Psikis terhadap Keberlangsungan Pendidikan Formal Anak

\section{1) Faktor Penyebab dan Bentuk Kekerasan pada Anak}

Kekerasan (violence) berasal dari kata latin yakni, vis yang berari daya, kekuatan dan latus yang berarti membawa. Secara sosiologis, kekerasan merupakan konflik sosial yang tidak terkendali dalam lingkup masyarakat yang terjadi karena adanya kekuatan untuk melakukan kerusakan (tindakan merusak) dengan mengabaikan norma dan nilai sosial.

Kekerasan terhadap anak (child abuse) adalah semua bentuk perlakuan menyakitkan secara fisik ataupun emosional, penyalahgunaan seksual, pelalaian, eksploitasi komersial atau eksploitasi lain, yang mengakibatkan cedera/kerugian nyata ataupun potensial terhadap kesehatan anak, kelangsungan hidup anak, tumbuh kembang 
anak, atau martabat anak, yang dilakukan dalam konteks hubungan tanggung jawab, kepercayaan, atau kekuasaan. ${ }^{7}$

Pentingnya mengetahui faktor-faktor yang menyebabkan adanya tindakan kekerasan terhadap anak untuk mencegah terjadinya kekerasan terhadap anak yang saat ini jumlahnya semakin meningkat. Jika berbicara mengenai sebab-sebab maka akan membahas mengenai teori viktimologi. Dalam teori viktimologi (ilmu yang memperlajari tentang korban) akan diketahui sebab-sebab dan akibat yang terjadi dengan adanya suatu tindakan kekerasan terhadap anak, yang dalam hal ini anak bertindak sebagai korban. Maka dengan mempelajari faktor-faktor yang menyebabkan kekerasan tersebut diharapkan dapat mengurangi jumlah kekerasan terhadap anak di masyarakat.

Faktor-faktor yang menjadi penyebab terjadinya kekerasan terhadap anak yaitu:

a) Faktor Lingkungan Sosial di sekitar anak yang keras, baik dalam bidang ekonomi, sosial, politik, budaya dan sebagainya.

b) Faktor Lingkungan Sekolah yang formalistis dan cenderung dehumanisasi.

c) Faktor dari sikap orang tua yang semakin permisif (serba membolehkan) terhadap ikatan nilai-nilai moral, serta intensitas komunikasi yang tidak lagi intens karena modernisasi dan profesionalisasi, yang menuntut individu menekuni keahliannya dan mengabdikan diri secara total kepada dunia kerja.

d) Faktor hilangnya ruang publik untuk ekspresi anak, seperti sedikitnya tempat untuk mengembangkan potensi anak dalam bidang olahraga, seni teater, musik, sastra, permainan kreatif dan sebagainya sehingga anak-anak lebih melampiaskan kepada hal-hal yang destruktif, tidak terkendali, tindakan coba-coba, tindakan mencari perhatian, melampiaskan

${ }^{7}$ Fakih M, Buku Panduan Pelatihan Deteksi Dini dan Penatalaksanaan Korban Child Abuse and Neglect (Jakarta, 2003), hlm. 77 heroisme di depan teman sebaya dan sebagainya. ${ }^{8}$

Melihat dari macam-macam faktor yang ada di atas dapat disimpulkan bahwa terdapat 2 (dua) faktor penting yang menyebabkan adanya kekerasan terhadap anak, yakni faktor internal dan faktor eksternal. Faktor internal (faktor dari dalam) dipengaruhi oleh diri anak itu sendiri dan faktor dari keluarga si anak. Sedangkan faktor eksternal (faktor dari luar) dipengaruhi oleh adanya faktor lingkungan tempat tinggal atau berinteraksinya si anak, faktor sistem pengajaran di lingkungan sekolah, maupun faktor teknologi.

Salah satu contoh yang paling terlihat dari tindak kekerasan yang dialami oleh anak-anak adalah terjadinya pemukulan atau penyerangan secara fisik berkali-kali sampai terjadi luka, lebam atau goresan. Namun demikian perlu disadari bahwa child abuse sebetulnya bukan hanya berupa pemukulan atau penyerangan fisik (yang terlihat) saja, melainkan juga berupa berbagai eksploitasi melalui pornografi dan penyerangan seksual (sexual assault), pemberian makanan yang tidak layak bagi anak atau makanan kurang gizi (malnutrition), pengabaian pendidikan dan kesehatan yang berkaitan dengan medis (medical abuse) ${ }^{9}$

Terry E. Lawson, membagi kekerasan terhadap anak (child abuse) menjadi 4 (empat) macam, yaitu: ${ }^{10}$

a) Emotional abuse (Kekerasan emosional) atau biasa disebut juga kekerasan psikis, terjadi ketika orang tua mengetahui anaknya membutuhkan perhatian, mereka justru mengabaikannya.

b) Verbal abuse (Kekerasan pada pengucapan/ lisan), terjadi ketika ibu mengetahui anaknya meminta perhatian,

8 Hadi Supeno, Kriminalisasi Anak: Tawaran Gagasan Peradilan Anak Tanpa Pemidanaan (Jakarta, 2010), hlm. 97 dan 98

9 Bagong Suyanto, (et.al.), Krisis dan Child Abuse (Surabaya, 2002), hlm. 114

${ }_{10}$ Terry E. Lawson. "Bentuk-bentuk Kekerasan pada Anak (Child Abuse)" dalam http://www.duniapsikologi.com/kekerasan-pada-anak, diakses tanggal 12 Mei 2014 
menyuruh anak itu untuk "diam" atau "jangan menangis".

c) Physical abuse (Kekerasan fisik), ketika terjadinya tindakan memukul anak (ketika sebenarnya anak membutuhkan perhatian) memukul anak dengan tangan, kayu, kulit, logam, atau benda-benda keras lainnya akan diingat oleh anak.

d) Sexual abuse (Kekerasan Seksual), Kekerasan jenis ini biasanya tidak terjadi selama delapan belas bulan pertama dalam kehidupan anak.

Segala bentuk kekerasan terhadap anak baik dalam bentuk kekerasan psikis, kekerasan fisik, verbal, maupun seksual akan memiliki dampak yang sama yakni timbulnya dampak psikis terhadap anak yang telah merasakan kekerasan tersebut, misalnya dikarenakan kekerasan terhadapnya, anak-anak akan mengalami trauma terhadap kejadian yang pernah dialaminya.

\section{2) Dampak Psikis Akibat Kekerasan pada Pendidikan Anak}

Penyia-nyiaan fisik yang sangat berpengaruh terhadap psikis yang berbentuk tindakan melalaikan anak, dapat berakibat kegagalan pertumbuhan, perkembangan dan pelajaran.

Kecemasan akibat adanya kekerasan terhadap anak telah menyebar ke semua kelas sosial. Tindakan kekerasan yang terjadi di lingkup sekolah dapat mengganggu pendidikan anak dalam kegiatan belajar-mengajar, mengurangi kepercayaan anak dan orang tua. Hal ini dikarenakan oleh tindakan kekerasan yang terjadi pada anak memiliki dampakdampak yang menakutkan. Baik dampak yang terlihat secara langsung seperti adanya luka. Maupun dampak secara tidak langsung seperti sikap atau perilaku anak yang berbeda karena gangguan pada mentalnya.

Menurut beberapa catatan yang dilakukan oleh para ahli perkembangan anak, kekerasan guru terhadap siswa juga memiliki dampak yang buruk untuk siswa terutama dalam kegiatan belajar mengajar. Dampak psikis yang dialami oleh siswa biasanya efek yang ditimbulkan dari sisi kejiwaan adalah rasa takut, malu bahkan trauma. Perbedaan perlakuan dari guru pada siswa yang melakukan pelanggaran dapat membuat siswa cenderung tidak percaya diri dan akhirnya prestasinya tidak akan berkembang. ${ }^{11}$

Dampak psikis akibat kekerasan yang lain, yaitu anak menarik diri dari lingkup rumah tangganya dan kata-kata kasar yang selalu diterimanya itu menjadi kebiasaan sendiri untuk berbicara seperti ini. Perkembangan kejiwaan juga mengalami gangguan, yaitu: gangguan kecerdasan, gangguan emosi, merasa diirinya jelek, tidak dicintai, tidak dikehendaki, muram dan tidak bahagia, tidak mampu menyenangi aktifitas, dan melakukan percobaan bunih diri, lebih agresif, kurang dapat bergaul, perubahan tingkah laku, kurang percaya diri, sering menyakiti diri sendiri, dan sering mencoba bunuh diri, tingkah laku atau pengetahuan seksual anak yang tidak sesuai dengan umumnya. ${ }^{12}$

Tindakan kekerasan baik fisik, seksual, ataupun psikis yang dialami anak-anak sesungguhnya adalah perilaku yang senantiasa akan memiliki dampak psikis.

Kekerasan yang berdampak psikis yang terjadi pada anak hanya bisa diketahui jenisnya dari dampak psikis yang dirasakan oleh tiap anak, karena kemampuan anak dalam menghadapi tindak kekerasan yang pernah dialami oleh dirinya berbeda-beda. Ada anak yang dapat menangani dampak kekerasan dengan lebih cepat dibandingkan dengan anak lain, ada pula yang merasakan trauma yang tidak bisa disembuhkan bahkan hingga anak tersebut menjadi dewasa. Bahkan beberapa kasus menyebutkan bahwa pelaku kekerasan terhadap anak merupakan korban kekerasan ketika masih anak-anak.

${ }^{11}$ Tim Beranda Agensi, Mengasuh dan Mendidik Buah Hati Tanpa Kekerasan (Jakarta, 2015), hlm. 61

${ }_{12}$ Lihat Daisy Widiastuti (et.al.), "Deteksi Dini, Faktor Risiko, dan Dampak Perlakuan Salah pada Anak, Sari Pediatri”, Vol,7, No.2, September 2005, hlm. 111 
Hal yang paling penting dalam mencegah terjadinya kekerasan terhadap anak adalah kontrol sosial. Masyarakat harus saling mengawasi perilaku masyarakat di lingkungan tempat tinggal masing-masing. Memperhatikan gerak-gerik masyarakat (keluarga, tetangga, lingkungan sekolah, dan lain-lain). Dengan pengawasan sadar yang dilakukan oleh masyarakat sekitar diharapkan kekerasan terhadap anak akan semakin berkurang.

Ada beberapa dokumen pendampingan terhadap korban kekerasan seksual yang diberikan pendampingan oleh LSM Penjara Indonesia yakni kasus pertama terjadi pada Januari Tahun 2019 di Pasuruan Jawa Timur, korban berinisial B (10 tahun) merupakan Siswi kelas 4 SDN Rebalas 2 Kecamatan Grati Pasuruan yang dicabuli ramai-ramai oleh 3 teman sekolah didalam kelas saat proses belajar mengajar. Akibatnya, korban mengalami trauma berat membuat tak mau sekolah. Pasca kejadian tersebut dirinya siswa kelas 4 warga Desa Rebalas Kecamatan Grati Pasuruan tersebut tak mau sekolah lagi. Korban masih trauma atas kejadian yang menimpa dirinya. Menurut orang tua korban, putri semata wayang pasangan BH (50 tahun) dan AS ( 45 tahun), diperkosa ketika guru kelas sedang ke toilet karena sakit perut. Korban awalnya diancam dengan cutter oleh dua pelaku yang tak lain tetangga rumahnya. Karena takut, korban pun menuruti nafsu bejat 3 bocah nakal tersebut. Korban diperkosa di atas meja ruang kelas, korban ditelanjangi dan digilir satu persatu oleh pelaku dengan disaksikan oleh teman-temannya. Meski begitu, temanya dalam satu kelas tak bisa berbuat apa-apa, karena takut dengan kenakalan pelaku. Usai melakukan nafsu bejadnya, mereka pulang ke rumah masingmasing. Sementara itu, Wakasek SDN Rebalas 2, Nurisiati, mengakui 3 anak yang mencabuli temannya tergolong nakal, meski sering sudah diberi nasihat. "Tetapi perilakunya tak berubah, hinga tidak naik kelas selama 4 kali.

Dari kasus di atas, kekerasan yang dilakukan oleh pelaku merupakan kekerasan seksual, walaupun kekerasan yang dilakukan adalah kekerasan seksual, namun timbul dampak psikis dari kekerasan tersebut.

Dari peristiwa saat kekerasan tersebut berlangsung sudah mengakibatkan dampak psikis yang sangat kuat dan terus menerus hingga kejadian itu berlalu kepada korban, korban diancam, dicabuli dan diperkosa di depan teman-teman kelasnyanya sendiri membuat korban merasa malu, takut, khawatir, martabatnya hilang, kepercayaan dirinya hilang, dan pasti ada trauma khususnya dilingkungan sekolah karena kejadian berlangsung disekolah dan pada saat proses belajar mengajar. Hal ini membuat korban tidak mau lagi untuk bersekolah.

Dari kasus tersebut menunjukan bahwa perlu ada jaminan perlindungan hukum bagi korban kekerasan yang berdampak psikis terhadap pendidikan anak. Hal ini perlu karena pendidikan merupakan salah satu hak anak yang dijamin dan dilindungi oleh konstitusi. Anak memiliki hak untuk memperoleh pendidikan yang aman dan nyaman. Berbagai macam kekerasan yang terjadi di lingkungan anak khususnya di lingkungan sekolah sangat mempengaruhi keinginan dan kemauan anak untuk menempuh pendidikan. Dampak psikis dari kekerasan-kekerasan tersebut, mengakibatkan terhambatnya tumbuh kembang otak anak, menghambat anak untuk berprestasi dan menjadikan anak yang kurang percaya kepada kemampuan dirinya.

\section{Data Pengaduan Anak sebagai Korban Kekerasan}

Tahun 2011-2016

\begin{tabular}{|c|c|c|}
\hline No. & Tahun & Jumlah \\
\hline 1. & 2011 & 56 \\
\hline 2. & 2012 & 130 \\
\hline 3. & 2013 & 96 \\
\hline 4. & 2014 & 159 \\
\hline
\end{tabular}




\begin{tabular}{|c|c|c|}
\hline 5. & 2015 & 154 \\
\hline 6. & 2016 & 97 \\
\hline
\end{tabular}

Sumber: KPAI, Tahun 2017

\section{3) Pengaturan Jaminan Perlindungan} Hukum bagi Anak Korban Kekerasan Fisik yang Berdampak Psikis terhadap Keberlangsungan Pendidikan Formal Anak

Hukum di dalam masyarakat khususnya dalam menghadapi perubahan masyarakat perlu dikaji dalam rangka mendorong terjadinya perubahan sosial. Hukum memiliki peran yang tidak langsung dalam mendorong munculnya perubahan sosial yang berpengaruh langsung terhadap masyarakat di wilayah Nusantara. Hukum memberikan jaminan perlindungan terhadap setiap orang dan sangat mempengaruhi kehidupan dalam bermasyarakat. ${ }^{13}$

Indonesia sebagai negara hukum jaminan atas perlindungan hukum dalam pelaksanaan segala aspek yang ada di masyarakat memiliki pengaruh yang sangat penting khususnya dalam memberikan jaminan perlindungan terhadap anak korban kekerasan yang berdampak psikis terhadap pendidikan anak. Pendidikan perlu mendapatkan perhatian oleh hukum karena pendidikan sangatlah penting bagi anak dan untuk mewujudkan amanat dari konstitusi.

Perlindungan hukum bagi anak diatur dalam Undang-Undang Dasar Negara Indonesia Pasal 28b Ayat (2) yang menyatakan bahwa "Setiap anak berhak atas kelangsungan hidup, tumbuh, dan berkembang serta berhak atas perlindungan dari kekerasan dan diskriminasi”. Namun seperti yang kita tahu bahwa Indonesia saat ini masih jauh dari kondisi yang disebutkan dalam pasal tersebut. Aturan lainnya terdapat dalam Undang-

13 Anonim, "Peran dan Fungsi Hukum" dalam https://www.kompasiana.com/nurhadiansyah0650/5baf1e 96bde575344f392483/peran-dan-fungsi-hukum?page=all, diakses tanggal 29 September 2019 pukul 14:00 oleh Kompasiana
Undang Nomor 35 Tahun 2014 tentang Perubahan Atas Undang-Undang Nomor 23 Tahun 2002 tentang Perlindungan Anak, Pasal 1 Ayat (2) bahwa Perlindungan Anak adalah segala kegiatan untuk menjamin dan melindungi anak dan hak-haknya agar dapat hidup, tumbuh, berkembang, dan berpartisipasi secara optimal sesuai dengan harkat dan martabat dan martabat kemanusiaan, serta mendapat perlindungan dari kekerasan dan diskriminasi.

Berkaitan dengan pemenuhan hak anak maka telah dibuat berbagai peraturan perundang-undangan penunjang yakni: Undang-undang Nomor 35 Tahun 2014 tentang Perubahan Atas Undang-undang Nomor 23 Tahun 2002 tentang Perlindungan Anak, Undang-undang Nomor 17 Tahun 2016 tentang Penetapan Peraturan Pemerintah Pengganti Undang-undang Tentang Perubahan Kedua Atas Undang-undang Nomor 23 Tahun 2002 Tentang Perlindungan Anak menjadi Undang-undang, Undang-undang Republik Indonesia Nomor 4 Tahun 1979 yang mengatur tentang Kesejahteraan Anak, Undang-undang Republik Indonesia Nomor 11 Tahun 2012 tentang Sistem Peradilan Pidana Anak, Undang-undang Republik Indonesia Nomor 39 Tahun 1999 tentang Hak Asasi Manusia (khusus pada pasal 52 sampai dengan pasal 66 yang mengatur tentang hak anak).

Amanat Undang-undang Hak Asasi Manusia Undang-undang No. 39 tahun 1999 Pasal 33 (1) menyatakan bahwa "Setiap orang berhak untuk bebas dari penyiksaan, penghukuman atau perlakuan kejam tidak manusiawi, merendahkan derajat dan martabat kemanusian", sedangkan Pasal 29 (1) menyatakan bahwa "Setiap orang berhak atas perlindungan diri pribadi, keluarga, kehormatan, martabat dan hak miliknya”.

Terkait kekerasan yang sering terjadi di lingkungan sekolah dalam Pasal 54 Undangundang Nomor 35 Tahun 2014 tentang Perubahan Atas Undang-undang Nomor 23 Tahun 2002 tentang Perlindungan Anak, ayat (1) mengatakan bahwa anak di dalam dan di 
lingkungan satuan pendidikan wajib mendapatkan perlindungan dari tindakan kekerasan fisik, psikis, kejahatan seksual, dan kejahatan lainnya yang dilakukan oleh pendidikan, tenaga kependidikan, sesama peserta didik, dan/atau pihak lain.

Adapun yang menjadi persoalan adalah bagaimana nasib anak korban kekerasan yang berdampak psikis terhadap pendidikan anak, dalam Peraturan Perundang-undangannya masih belum mengatur secara khusus dan masih kabur tentang bentuk pemidanaan bagi pelaku kekerasan yang berdampak psikis dan upaya hukum bagi anak korban kekerasan.

Jaminan perlindungan hukum terhadap pendidikan anak dalam lingkup pendidikan sebenarnya sudah jelas contohnya seperti adanya peraturan perundang-undangan yang mengatur tentang pendidikan seperti Undangundang Republik Indonesia Nomor 20 Tahun 2003 tentang Sistem Pendidikan Nasional, Peraturan Pemerintah Nomor 32 Tahun 2013 tentang Perubahan Atas Peraturan pemerintah Nomor 19 Tahun 2006 tentang Standarisasi Nasional Pendidikan, dan lain sebagainya.

Pandangan Satjipto mengenai karakteristik dan fungsi serta peranan hukum dalam pembangunan dibedakan dalam dua hal yaitu pertama, hukum selalu ditempatkan untuk mencari landasan pengesahan atas suatu tindakan yang memegang teguh ciri prosedural dari dasar hukum dan dasar peraturan. Kedua, hukum dalam pembangunan adalah sifat instrumental yang dipandang telah mengalami pertukaran dengan kekuatan-kekuatan di luar hukum sehingga hukum menjadi saluran untuk menjalankan keputusan politik atau hukum sebagai perekayasa sosial. ${ }^{14}$

Menurut Ki Hajar Dewantara merumuskan pengertian pendidikan sebagai daya upaya untuk memajukan bertumbuhnya budi pekerti (kekuatan batin, karakter), pikiran (intelektual dan tubuh anak). Dalam Taman Siswa, tidak boleh dipisahkan bagian-bagian

14 Romli Atmasasmita, Teori Hukum Integratif Rekonstruksi Terhadap Teori Hukum Pembangunan dan Teori Hukum Progresif (Yogyakarta, 2012), hlm. 87-88 itu agar kita memajukan kesempurnaan hidup, kehidupan, kehidupan dan penghidupan anakanak yang kita didik, selaras dengan dunianya. ${ }^{15}$

Menurut Undang-undang Nomor 20 Tahun 2003 Pasal 1 Ayat (1) sebagai berikut: "Pendidikan adalah usaha sadar dan terencana untuk mewujudkan suasana belajar dan proses pembelajaran agar peserta didik secara aktif mengembangkan potensi dirinya untuk memiliki kekuatan spiritual keagamaan, pengendalian diri, kepribadian, kecerdasan, akhlak mulia, serta ketrampilan yang diperlukan dirinya, masyarakat,bangsa dan negara". Pada Ayat (2) disebutkan bahwa "pendidikan nasional adalah pendidikan yang berdasarkan Pancasila dan Undang-undang Dasar Negara Republik Indonesia (UUD NRI) Tahun 1945 yang berakar pada nilai agama, kebudayaan nasional Indonesia dan tanggap terhadap tuntutan perubahan zaman." Pada Ayat (3) disebutkan bahwa "sistem pendidikan nasional adalah keseluruhan komponen pendidikan yang saling terkait secara terpadu untuk mencapai tujuan pendidikan nasional."

Ketersediannya aturan atau undangundang di atas dalam melindungi anak dari kekerasan masih belumlah cukup. Pada kenyataannya semakin modern zaman maka bentuk kekerasan terhadap anak juga semakin beragam. Seperti salah satunya kekerasan yang berdampak psikis pada anak. Kekerasan dalam bentuk ini masih belumlah di atur dalam Perundang-undangan di Indonesia.

\section{B. Bentuk Pengaturan Perlindungan Hukum yang Tepat bagi Anak Korban Kekerasan Fisik yang Berdampak Psikis terhadap Keberlangsungan Pendidikan Formal Anak}

\section{1) Perlindungan dengan Pendekatan Hukum}

15 Ki Hajar Dewantara, Karya Ki Hajar Dewantara, (Yogyakarta, 1977), hlm. 14 
Perlindungan hukum sebagai suatu bentuk pelayanan yang wajib dilaksanakan oleh aparat penegak hukum atau aparat keamanan untuk memberikan rasa aman, baik fisik maupun mental, kepada korban dan sanksi dari ancaman, gangguan, teror, dan kekerasan dari pihak manapun.

Perlindungan hukum tersebut dapat berupa peraturan perundang-undangan atau tindakan hukum, atau sanksi pidana. Aturan hukum tidak hanya untuk kepentingan jangka pendek saja, akan tetapi harus berdasarkan kepentingan jangka panjang. Perlindungan hukum adalah suatu perlindungan yang diberikan terhadap subyek hukum dalam bentuk perangkat hukum baik yang bersifat preventif maupun yang bersifat represif, baik yang tertulis maupun tidak tertulis. Dengan kata lain perlindungan hukum sebagai suatu gambaran dari fungsi hukum yaitu konsep di mana hukum dapat memberikan suatu keadilan, ketertiban, kepastian, kemanfaatan dan kedamaian.

Salah satu bentuk perlindungan hukum adalah perlindungan dengan pendekatan hukum yang merupakan cara memanfaatkan sarana pidana atau sanksi pidana. Kasus kekerasan terhadap anak seharusnya penanganannya tidak hanya bertumpu pada Undang-undang tentang Perlindungan anak saja, tetapi juga dikaitkan dan saling singkron dengan undang-undang lainnya seperti salah satunya Undang-undang tentang Sistem Pendidikan Nasional. Undang-undang tentang Sistem Pendidikan Nasional hanya menekankan pada mutu pendidikan dan pengawasan atas penyelenggaraan pendidikan pada semua jenjang dan jenis pendidikan. Seharusnya dalam Undangundang tentang Sistem Pendidikan Nasional, pihak sekolah wajib memberikan pengawasan tidak hanya berkaitan dengan mutu pendidikan tetapi juga melakukan pengawasan terhadap segala hal perilaku anak didik dan lingkungan sekolah sehingga aman untuk anak didik.
Secara sederhana dapatlah dibedakan, bahwa upaya penanggulangan kejahatan lewat jalur "hukum" lebih menitik beratkan pada sifat "repressive" (penindasan/pemberantasan/penumpasan) sesudah kejahatan terjadi. Upaya penanggulangan hukum pidana melalui sarana dalam mengatur masyarakat lewat perundangundangan pada hakikatnya merupakan wujud suatu langkah kebijakan (policy).

Upaya penanggulangan kejahatan dengan hukum pidana lebih menitik beratkan pada sifat "Represive" (Penindasan/ pemberantasan/ penumpasan), setelah kejahatan atau tindak pidana terjadi. Oleh karena itu, kebijakan hukum pidana merupakan bagian dari kebijakan penegak hukum (Law Enforcement). Hukuman atau sanksi pidana yang dijatuhkan kepada pelaku diharapkan dapat memberikan efek jerah kepada pelaku sesuai dengan tujuan pemidanaan.

Dasar hukum dalam menanggulangi permasalahan berkaitan dengan kekerasan yang berdampak psikis pada anak perlu di atur dalam Peraturan Perundang - undangan Indonesia.

Berikut Tabel klasifikasi bobot delik: ${ }^{16}$

\begin{tabular}{|l|l|l|}
\hline $\begin{array}{l}\text { Bobot } \\
\text { Delik }\end{array}$ & $\begin{array}{l}\text { Jenis } \\
\text { Pidana }\end{array}$ & \multicolumn{1}{|c|}{ Keterangan } \\
\hline $\begin{array}{l}\text { Sangat } \\
\text { Ringan }\end{array}$ & Denda & $\begin{array}{l}- \text { Perumusannya } \\
\text { tunggal } \\
\text { - Denda Ringan }\end{array}$ \\
\hline Berat & $\begin{array}{l}\text { Penjara } \\
\text { dan } \\
\text { Denda }\end{array}$ & $\begin{array}{l}- \text { Perumusannya } \\
\text { alternatif } \\
-\quad \text { Penjara 1-7 } \\
\text { tahun }\end{array}$ \\
\hline $\begin{array}{l}\text { Sangat } \\
\text { Serius }\end{array}$ & -Penjara & $\begin{array}{l}- \text { Perumusannya } \\
\text { tunggal }\end{array}$ \\
\hline
\end{tabular}

16 Lihat M.Syamsu Rizal, "Model Kebijakan Penal dalam Upaya Pencegahan Kejahatan Seksual terhadap Anak (Sexual Crime on Child)" (Surakarta, 2016), Fakultas Hukum Universitas Muhammadiyah, hlm. 16 


\begin{tabular}{|l|l|l|}
\hline & - Mati & $\begin{array}{l}\text {-Dapat } \\
\text { diakumulasikan } \\
\text { dengan denda }\end{array}$ \\
\hline
\end{tabular}

Terkait upaya hukum yang diberikan kepada pelaku kekerasan yang berdampak pada psikis anak jika ditinjau berdasarkan bobot delik, kekerasan kepada anak termasuk delik berat sehingga jenis pidana yang dapat dikenakan pada pelaku kekerasan adalah pidana penjara dan denda serta pelaku dikenakan tanggung jawab membiayai rehabilitasi anak korban hingga pulih.

Sedangkan perlindungan hukum bagi korban kekerasan fisik yang berdampak psikis terhadap keberlangsungan pendidikan formal anak yakni dengan memuat pengaturan mengenai hak-hak korban kekerasan baik itu korban kekerasan fisik atau psikis didalam undang-undang, sehingga apabila ada korban kekerasan fisik yang berdampak pada psikis anak, maka korban dapat segera diberikan hakhaknya sesuai dengan aturan yang telah ditetapkan dalam undang-undang.

\section{2) Perlindungan dengan Pendekatan Non Hukum}

Upaya perlindungan dan penanggulangan kejahatan perlu ditempuh dengan pendekatan kebijakan yang meliputi adanya keterpaduan (integritas) antara politik kriminal dan politik sosial dan keterpaduan antara upaya penanggulangan kejahatan dan dampaknya bagi korban dengan hukum dan non hukum. Dalam persoalan perlindungan bagi anak korban kekerasan yang berdampak psikis terhadap pendidikan anak, penggunaan sarana hukum tidak cukup efektif dilihat dari masih tingginya kekerasan pada anak. ${ }^{17}$

Ketidak pedulian masyarakat yang tidak mau membuka diri ikut mendukung anak korban dan keengganan masyarakat untuk

${ }^{17}$ Loc. cit , hlm. 138 melaporkan tindakan kekerasan terhadap anak karena masyarakat sulit untuk mendobrak tradisi lama yang mau berurusan dengan aparat penegak hukum, maka sesempurna apapun aturan perundang-undangan yang dibuat dan mengandung unsur pidana untuk membuat jera pelaku, akan kurang efektif jika tanpa peran serta masyarakat dan pihak lain disekeliling anak korban. Maka langkah yang harus ditempuh adalah dengan menggunakan sarana non hukum. Sarana non hukum dilakukan dengan usaha pencegahan dan penanggulangan tanpa menggunakan Hukum Pidana (Prevention without punishment) termasuk di dalamnya penerapan sanksi administratif dan sanksi perdata juga. Sarana non hukum juga dilakukan dengan melibatkan berbagai komponen dalam masyarakat dan orang terdekat yang berada di lingkungan tumbuh kembang anak. ${ }^{18}$

Upaya perlindungan hukum kepada anak korban kekerasan yang berdampak psikis terhadap pendidikan anak dengan menerapkan sistem non hukum yaitu memberikan rehabilitasi kepada anak baik dari pemerintah maupun dari pihak pelaku kekerasan.

Rehabilitasi adalah sebuah kegiatan ataupun proses untuk membantu para penderita yang mempunyai penyakit serius seperti trauma atau cacat yang memerlukan pengobatan medis untuk mencapai kemampuan fisik, psikologis, dan sosial yang maksimal. ${ }^{19}$

Untuk pencegahan di lingkungan sekolah, sekolah diharuskan memiliki guru bimbingan konseling (BK) yang memiliki sertifikat penanganan kekerasan kepada anak, di setiap sekolah penting untuk merekrut guru bimbingan konseling yang memahami

18 Taufan Symposion, "Upaya Non Penal dalam Menanggulangi Kejahatan" dalam http://kilometer25.blogspot.com/2012/09/upaya-nonpenal-dalam-menanggulangi.html, diakses tgl 24 September 2012

${ }^{19}$ David Arnot (et.al.) Pustaka kesehatan Populer Pengobatan Praktis: perawatan Alternatif dan Tradisional, Jakarta (PT Bhuana Ilmu Populer, 2009), hlm. 180. 
psikologi anak korban kekerasan, karena psikologi sangat berpengaruh pada tumbuh kembang anak. Oleh karena itu penting bagi pemerintah meninjau kembali sistem perekrutan guru bimbingan konseling dilingkungan sekolah dan lebih memperhatikan tingkah laku anak didiknya.

Pembenahan terhadap faktor yang mempengaruhi lingkungan/eksternal anak yakni pergaulan yang perlu dibatasi dan terkontrol serta norma yang sopan dan santun yang ada di masyarakat ditanamkan dalam diri anak. Pembenahan terhadap teknologi yang mana teknologi saat ini berisi konten-konten yang kurang baik untuk di tiru oleh anak-anak. Segala komunikasi anak lebih mudah lewat media sosial, namun seringkali media sosial dijadikan alat untuk melakukan kekerasan dengan cara menghina, menghujat, menyindir temannya sendiri (cybercrime).

Untuk mencapai perlindungan bagi anak korban kekerasan yang berdampak psikis terhadap pendidikan anak maka diperlukan adanya sinergi dari masing-masing pihak terkait yang memiliki peranan di dalamnya, seperti:

\section{Pemerintah}

Pemerintah dalam hal ini yaitu seluruh pemerintah Republik Indonesia, khususnya Pemerintah Daerah dan Dinas terkait seperti Dinas Pendidikan dan Dinas Sosial. Pemerintah yang memiliki peran dalam menjamin terlaksananya perlindungan hukum terhadap anak korban kekerasan, haruslah memantau secara langsung dan melakukan pembenahan terhadap norma hukum, sehingga hukum mengikuti perkembangan saat ini. Pemerintah melakukan mitra kerja dengan berbagai pihak atau lembaga agar peran kontrol itu terlaksana dengan baik dan saling mendukung. Sehingga segala upaya yang dilakukan bersama dapat mencapai yang diinginkan yaitu pencegahan terhadap terjadinya kekerasan kepada anak serta anak mendapat pendidikan yang aman dan nyaman.
2. Komisi Perlindungan Anak Indonesia

Komisi Perlindungan Anak Indonesia (KPAI) memiliki peran yang cukup strategis melihat dari fungsi dan Tugas Komisi Perlindungan Anak Indonesia (KPAI), KPAI melakukan pengumpulan data, informasi, menerima pengaduan masyarakat, melakukan penelaahan, pemantauan, evaluasi dan pengawasan terhadap apapun. ${ }^{20}$ KPAI harus terus aktif dalam hal sosialisasi dan advokasi tentang peraturan perundang-undangan yang berkaitan dengan perlindungan anak; KPAI tidak hanya menerima pengaduan namun juga harus selalu melakukan survei di lapangan; KPAI juga harus lebih kritis dan melakukan pengkajian peraturan perundang-undangan, kebijakan pemerintah, dan kondisi pendukung lainnya baik di bidang sosial, ekonomi, budaya dan agama; KPAI harus selalu aktif dan memberikan masukan, saran dan pertimbangan kepada berbagai pihak terutama Presiden, DPR, Instansi pemerintah terkait ditingkat pusat dan daerah; Mengumpulkan Melakukan pemantauan, evaluasi, dan pelaporan tentang perlindungan anak termasuk laporan untuk Komite Hak Anak PBB (Committee on the Rights of the Child) di Geneva, Swiss; Melakukan pengawasan terhadap penyelenggara perlindungan anak di Indonesia.

\section{Polri sebagai Penegak Hukum}

Polri sebagai penegak hukum memiliki andil dalam menegakan amanat konstitusi untuk menjamin perlindungan hukum terhadap anak korban kekerasan. Polri harus membangun suasana positif di lingkungan masyarakat dan melakukan kerja sama dengan masyarakat serta pemerintah dan lembaga yang terkait.

\section{Pihak Orang Tua/Keluarga}

20 Lihat Hilman Reza, "Peran Komisi Perlindungan Anak Indonesia Dalam Mengatasi Kekerasan Seksual Terhadap Anak”, Penulisan Skripsi Fakultas Syari'ah dan Hukum Univeritas Islam Negeri Syarif Hidayatullah (Jakarta, 2014), hlm. 6 
Orang tua merupakan tempat pertama kali anak memperoleh perlindungan. Orang tua memiliki peran dalam perkembangan baik pendidikan, sosial, intelektual dan psikologis. Orang tua harus membangun suasana akrab dengan anak agar anak merasa mendapatkan perlindungan, keamanan dan kasih sayang. Oleh karena itu, orang tua tidak boleh lalai dalam mengawasi dan mengontrol tumbuh kembang anak. Orang tua juga harus membangun suasana akrab dengan lingkungan sekitar anak, baik di lingkungan pendidikan yaitu orang tua selalu mengawasi perkembangan anak dengan memantau anak dari guru, di lingkungan sosial yaitu orang tua tidak melarang anak dalam bergaul namun dalam pergaulan anak orang tua harus mengawasi pergaulan anak, orang tua diposisikan sebagai sahabat dalam dunia pergaulan anak.

\section{Lingkungan Masyarakat}

Peran masyarakat di lingkungan sosial anak terhadap perlindungan anak dari kekerasan anak sangat penting. Masyarakat dapat menilai dan mengamati anak-anak di sekitar lingkungannya. Ketika melihat anak di lingkungannya tersakiti atau menjadi korban kekerasan, mayarakat dapat mengawasi, membantu melindungi, dan menghibur anak tersebut.

\section{Lingkungan Pendidikan}

Lingkungan pendidikan erat kaitannya dengan anak-anak. Jika berbicara pendidikan anak, maka akan berbicara mengenai sekolah tempat anak menimba ilmu. Anak-anak menghabiskan banyak waktu di sekolahnya tidak hanya untuk mencari ilmu akademik saja, namun juga mencari teman, mengasah kreatifitas dan hobinya (melakukan ekstrakurikuler) yang dilakukan di sekolah pula.

Kehadiran guru dalam proses pembelajaran sebagai sarana mewariskan nilainilai dan norma-norma masih memegang peranan yang sangat penting.
Guru sebagai orang yang bertanggung jawab di sekolah perlu mengajarkan hal-hal yang baik kepada anak. Selain itu guru perlu mengawasi tingkah laku anak-anak di sekitarnya. Karena anak-anak yang pernah mengalami kekerasan akan terlihat berbeda dari anak-anak normal lainnya. Guru harus bisa melindungi dan mengawasi anak-anak tersebut, mencari solusi dari permasalahan anak dan membantunya keluar dari permasalahan tersebut.

\section{Pers}

Pers sebagai wadah dalam keterbukaan informasi dan kebebasan berpendapat, maka kebebasan pers adalah kebebasan berkomunikasi dan berekspresi dalam memberikan informasi kepada publik melalui media massa, baik media cetak maupun media elektronik. Pers yang dimaksudkan di sini yakni para pencari berita, baik berita yang akan ditayangkan di televisi maupun media sosial dan koran. Pers menyajikan berita yang baik dan benar adanya mengenai adanya berbagai macam bentuk-bentuk kekerasan yang dapat terjadi pada anak-anak. Diharapkan dengan adanya pers dapat memberikan kewaspadaan kepada orang-orang yang bertanggung jawab terhadap anak-anak, baik orang tua maupun guru di sekolah untuk lebih mengawasi anakanak atau anak didik mereka.

Perlindungan dalam bentuk non hukum sebagai pencegahan adanya kekerasan pada anak lainnya yakni sebagai contoh peran Pemerintah Daerah Kabupaten Pasuruan yang secara substansial Pemerintah Daerah memberikan perlindungan terhadap anak dengan dibuatnya Peraturan Bupati Pasuruan Nomor 21 Tahun 2016 Tentang Wajib Belajar Pendidikan Madrasah Diniyah. Pemerintah Daerah ingin membuat corak pendidikan di daerahnya tidak hanya berpusat hanya pendidikan akademik saja melainkan juga akhlak, dengan mendalami ilmu-ilmu agama Islam untuk dipahami dan diamalkan oleh anak-anak di daerahnya. Selain itu diharapkan dengan mendalami agama, maka anak-anak 
dapat menghargai dan mengasihi teman-teman di lingkungannya, sehingga mencegah terjadinya kekerasan pada anak di lingkungan.

\section{PENUTUP}

Berdasarkan uraian yang terdapat dalam analisis hasil di atas, maka dapat diperoleh beberapa kesimpulan sebagai berikut:

1. Tindak kekerasan terhadap anak dianggap sebagai masalah sosial yang perilakunya merupakan perbuatan menyimpang dalam masyarakat. Faktor yang menyebabkan adanya kekerasan terhadap anak, yakni faktor internal dan faktor eksternal. Kekerasan terhadap anak baik dalam bentuk kekerasan psikis, kekerasan fisik, verbal, maupun seksual akan memiliki dampak yang sama yakni timbulnya dampak psikis terhadap anak yang telah merasakan kekerasan tersebut. Bentuk jaminan perlindungan hukum bagi anak korban kekerasan fisik yang berdampak psikis terhadap keberlangsungan pendidikan formal anak di Indonesia masih belum ada atau peraturannya masih kabur. Sehingga korban yang mengalami kekerasan yang berdampak psikis tidak bisa dimintai pertanggungjawaban kepada pelaku tindak kekerasan tersebut. Padahal dampak dari terganggunya psikis anak yakni terancamnya psikologi anak dan terhambatnya pendidikan anak.

2. Bentuk perlindungan hukum yang tepat bagi anak korban kekerasan fisik yang berdampak psikis terhadap keberlangsungan pendidikan formal anak yaitu dengan menerapkan perlindungan dengan pendekatan hukum dan Non Hukum. Dalam bentuk upaya hukum yang diberikan kepada pelaku kekerasan jika ditinjau berdasarkan bobot delik, kekerasan kepada anak termasuk delik berat sehingga jenis pidana yang dapat dikenakan pada pelaku kekerasan adalah pidana penjara dan denda serta pelaku dikenakan tanggung jawab membiayai rehabilitasi anak korban hingga pulih, menerapkan pelaksanaan sistem peradilan anak dan pelaku kekerasan dikenai ganti kerugian dalam bentuk materil maupun dalam bentuk pemidanaan. Dalam bentuk upaya non hukum yaitu memberikan rehabilitasi kepada anak baik dari pemerintah maupun dari pihak pelaku kekerasan. Dalam lingkungan sekolah juga penting untuk memiliki guru bimbingan konseling yang memiliki sertifikat penanganan kekerasan kepada anak agar anak mendapat penanganan yang cepat dan dapat memahami psikologi anak korban kekerasan.

Dari kesimpulan di atas maka terdapat beberapa saran untuk dijadikan masukan yakni untuk mencapai perlindungan hukum bagi anak korban kekerasan yang berdampak psikis terhadap pendidikan anak maka diperlukan adanya sinergi dari masing-masing pihak terkait yang memiliki peranan di dalamnya, seperti pemerintah, kementerian pemberdayaan perempuan dan perlindungan anak, komisi perlindungan anak Indonesia, pihak penegak hukum, pihak orang tua, lingkungan masyarakat, lingkungan pendidikan dan pers. Selain itu peraturan perundangundangan terkait perlindungan bagi anak korban dan pendidikan perlu saling singkron dengan Undang-undang lainnya seperti salah satunya Undang-undang tentang Sistem Pendidikan Nasional. Penting pula bagi pemerintah meninjau kembali sistem perekrutan guru bimbingan konseling di lingkungan sekolah. Oleh karenanya maka perlu ada revisi dalam undang-undang perlindungan anak untuk menambahkan terkait jaminan perlindungan bagi anak korban yang berdampak psikis terhadap pendidikan anak.

\section{DAFTAR PUSTAKA}

\section{Buku-buku}

Arnot, David, (et.al.). 2009. Pustaka kesehatan Populer Pengobatan Praktis: perawatan Alternatif dan Tradisional. Jakarta: PT Bhuana Ilmu Populer. 
Atmasasmita, Romli. 2012. Teori Hukum Integratif Rekonstruksi Terhadap Teori Hukum Pembangunan dan Teori Hukum Progresif. Yogyakarta: Genta Publishing

Beranda Agensi, Tim. 2015. Mengasuh dan Mendidik Buah Hati Tanpa Kekerasan. Jakarta: PT. Elex Media Komputindo

Dewantara, Ki Hajar. 1977. Karya Ki Hajar Dewantara. Yogyakarta: Majelis Luhur Persatuan Taman Siswa

M., Fakih. 2003. Buku Panduan Pelatihan Deteksi Dini dan Penatalaksanaan Korban Child Abuse and Neglect. Jakarta: IDI-UNICEF

Supeno, Hadi. 2010. Kriminalisasi Anak: Tawaran Gagasan Peradilan Anak Tanpa Pemidanaan. Jakarta: PT. Gramedia Pustaka Utama

Suyanto, Bagong (et.al). 2002. Krisis dan Child Abuse. Surabaya: Airlangga University

Jurnal/ Penulisan Hukum/ Makalah

Reza, Hilman. 2014. "Peran Komisi Perlindungan Anak Indonesia Dalam Mengatasi Kekerasan Seksual Terhadap Anak". Penulisan Skripsi. Jakarta: Fakultas Syari'ah dan Hukum Univeritas Islam Negeri Syarif Hidayatullah

Rizal, Muhammad Syamsu. 2016. "Model Kebijakan Penal dalam Upaya Pencegahan Kejahatan Seksual terhadap Anak (Sexual Crime on Child)". Surakarta: Fakultas Hukum Universitas Muhammadiyah

Widiastuti, Daisy (et.al). 2005. "Deteksi Dini, Faktor Risiko, dan Dampak Perlakuan Salah pada Anak". Sari Pediatri, Vol,7, No.2, September

Peraturan Perundang-undangan
Undang-undang Republik Indonesia Nomor 4 Tahun 1979 tentang Kesejahteraan Anak (Lembaran Negara Republik Indonesia Tahun 1979 Nomor 32, Tambahan Lembaran Negara Republik Indonesia Nomor 3143)Undang-undang Republik Indonesia Nomor 20 Tahun 2003 tentang Sistem Pendidikan Nasional (Lembaran Negara Republik Indonesia Tahun 2003 Nomor 78, Tambahan Lembaran Negara Republik Indonesia Nomor 4419)

Undang-undang Republik Indonesia Nomor 39 Tahun 1999 tentang Hak Asasi manusia (Lembaran Negara Republik Indonesia Tahun 1999 Nomor 165, Tambahan Lembaran Negara Republik Indonesia Nomor 3886)

Undang-undang Republik Indonesia Nomor 11 Tahun 2012 tentang Sistem Peradilan Pidana Anak (Lembaran Negara Republik Indonesia Tahun 2012 Nomor 153, Tambahan Lembaran Negara Republik Indonesia Nomor 5332)

Undang-undang Republik Indonesia Nomor 35 Tahun 2014 tentang perubahan atas Undang-undang Nomor 23 Tahun 2002 tentang Perlindungan Anak (Lembaran Negara Republik Indonesia Tahun 2002 Nomor 109, Tambahan Lembaran Negara Republik Indonesia Nomor 4235)

\section{Data dalam Jaringan}

Anonim, "Peran dan Fungsi Hukum" dalam https://www.kompasiana.com/nurhadians yah0650/5baf1e96bde575344f392483/per an-dan-fungsi-hukum?page=all, diakses tanggal 29 September 2019

Lihat Anonim, “Kekerasan" dalam https://id.wikipedia.org/wiki/kekerasan, diakses tgl. 23 Januari 2018

Lihat Anonim, "KPAI: Terjadi 33 Kasus Kekerasan Pada Anak Selama April-Juli 2018” dalam 
https://www.idntimes.com/news/indonesia /indianamalia/kpai-terjadi-33-kasus-

kekerasan-pada-anak-selama-april-

juli/full, diakses tgl. 13 Agustus 2018

Lihat Anonim, "Macam-macam Kekerasan" dalam

http://ssyarof.blogspot.co.id/2013/06/mac

am-macam-kekerasan.html, diakses tgl.

10 Juni 2013

Hendriani, Dedi. “Catatan Akhir Tahun KPAI

meneropong Persoalan Anak" dalam

http://www.kpai.go.id/berita/catatan-

akhir-tahun-kpai-meneropong-persoalan-

anak, diakses tgl. 31 Desember 2017

Jyestha, Vicentius. “KPAI Soroti Kasus

Kekerasan Pendidikan yang Masih

Tinggi” dalam

http://www.tribunnews.com/nasional/201

8/05/02/kpai-soroti-kasus-kekerasan-

pendidikan-yang-masih-tinggi, diakses tgl. 2 Mei 2018

Lawson, Terry E. “Bentuk-bentuk Kekerasan pada Anak (Child Abuse)" dalam http://www.duniapsikologi.com/kekerasan -pada-anak, diakses tanggal 12 Mei 2014

Rahayu, Cici Marlina. "Begini Urutan

Kejadian Siswi SMP Bully Siswi SD di Thamrin City” dalam http://news.detik.com/berita/d-

3562776/begini-urutan-kejadian-siswismp-bully-siswi-sd-di-thamrin-city, diakses tgl. 17 Juli 2018

Symposion, Taufan. "Upaya Non Penal dalam Menanggulangi Kejahatan” dalam http://kilometer25.blogspot.com/2012/09/ upaya-non-penal-dalam-

menanggulangi.html, diakses tgl 24 September 2012 